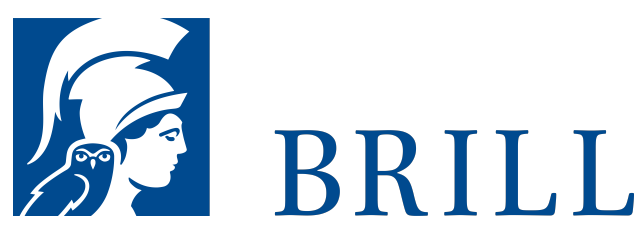

\title{
Zwischen katholischem Milieu und Nation
}

Literatur und Literaturkritik im Hochland (1903-1918)

Author: Maria Cristina Giacomin

Die Spannung zwischen Kirche und Welt, zwischen Katholizismus und Moderne bildet den Hintergrund dieser Untersuchung zum literarischen Anspruch der 1903 von Karl Muth gegründeten Zeitschrift Hochland. Mit einem kritischen Blick auf die von widersprüchlichsten Strömungen durchsetzte konfessionelle Kultur ist dieses Buch ein unverzichtbarer Beitrag zu einem differenzierteren literaturhistorischen Bild der Epoche von der Jahrhundertwende bis zum Ersten Weltkrieg. Inwieweit konnte Hochland das katholische Milieu durchbrechen? Wie artikulierte sich der Versuch der Zeitschrift, Anschluss an die deutsche Kultur zu finden und welche 'deutsche Kultur' galt ihr als Leitbild? Welche Funktion hatte Hochland für eine 'Wiederbegegnung von Kirche und Kultur'? In der Diskussion der ästhetischen und literarischen Fragen vor dem Hintergrund der politischen und sozialen, der theologischen und wissenschaftsgeschichtlichen Problemfelder der Epoche bis zum Ersten Weltkrieg wird das ambivalente und spannungsgeladene Verhältnis von katholischem Milieu und Nation deutlich. In einer facettenreichen Analyse entwirft die Autorin ein kritisches und streckenweise korrigierendes Bild des Anspruchs von Zeitschrift und Herausgeber, eine katholische Hochliteratur zu fördern und zu etablieren.

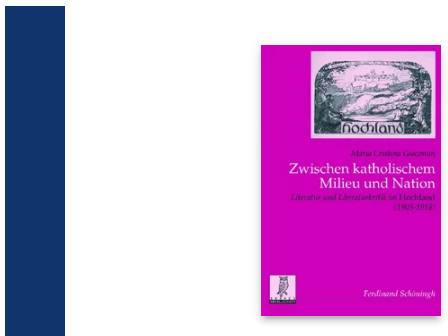

Pages: 428

Seiten

Language:

German

Subjects:

German,

Literature and

Cultural Studies

Publisher: Brill |

Schöningh

Series:

Politik- und

Kommunikationswissenschaftliche Veröffentlichungen der Görres-

Gesellschaft, Volume: 29

E-Book (PDF)

Released online:

29 Oct 2019

ISBN: 978-3-

657-76729-8

List price

USD $\$ 84.00$

Paperback

Publication date:

17 Jun 2009

ISBN: 978-3-

5o6-76729-5

List price

USD $\$ 84.00$ 
For more information see brill.com

Order information: Order online at brill.com +44330 3330049 | customerservices@brill.com Submission information: brill.com/authors

Titles published by Brill | Fink, Brill | mentis or Brill | Schöningh: +49(o)71 5413279216 | brill@brocom.de 